\title{
Personal, Socio-economic and Psychological Characteristics Contributing for Farmer Suicides in Karnataka
}

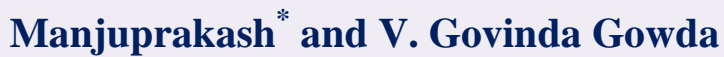

Department of Agricultural Extension and Agricultural Extension, College of Agriculture, Chamarajanagara, University of Agricultural Sciences, GKVK, Bangalore, India

*Corresponding author

\section{A B S T R A C T}

\section{Keywords}

Affected farmers, Agriculture, Compensation, Factors and farmer suicide

\section{Article Info}

Accepted: 12 December 2020 Available Online: 10 January 2021
Agriculture continues to be prominent sector for the Indian economy as it is the primary source of livelihood for over $58 \%$ of the nation's population and generates employment opportunity for $44 \%$ of the workforce. Farmers depend on climate to reap good harvest. The loss in one or more seasons will arrest the routine activities of farmers as their main source of income is from agriculture, this crisis will make life complications and farmer takes drastic step of committing suicide. In this background, a study was conducted in Mandya district of Karnataka to understand the factors responsible for suicides among the farmers. The list of the farmer suicides and the families of the same who availed the compensation of Rs. 5 lakh was considered for obtaining the information on the affected farmers from the Karnataka State Department of Agriculture. Personal interview method was followed in collecting the data. The data was analysed using percentage and frequency. The results of the study revealed that, less than half $(46.66 \%)$ were of old age group, 43.33 per cent were illiterates. Majority $(70.00 \%)$ of them were practicing agriculture as the main occupation, 63.33 per cent of them had high level of farming experience. More than half $(53.33 \%)$ of them were large farmers, majority $(70.00 \%)$ of them had nuclear family type. Further, 70.00 per cent of them belonged to Other Backward Class (OBC), 46.67 per cent belonged to medium level of cosmopoliteness, half (50.00\%) had medium level of mass media exposure, more than half $(56.67 \%)$ had low level of extension agency contact and extension participation. 46.66 per cent had medium level of economic motivation, half $(50.00 \%)$ had medium level of scientific orientation, 46.66 per cent of them had medium level of information seeking behaviour, more than half (56.67 $\%$ ) had medium level of innovativeness, 43.33 per cent of affected famers had medium level of risk orientation, 60.00 per cent had medium level of management orientation, more than half $(56.67 \%)$ had medium level of decision making ability and less than half $(46.67 \%)$ had high level of deferred gratification.

\section{Introduction}

Agriculture continues to be prominent sector for Indian economy as it is the primary source of livelihood for over $58 \%$ of the nation's population and generates employment for 44 $\%$ of the workforce (Rahul, 2020). Agriculture is more vulnerable to climate and 
it has adverse effects on the yield of the crops. As farmers depend mainly on agriculture for their livelihood, failure of crops for more than one season continuously will hit them hardly leading to economic crisis among the farmers. The problems that an individual farmers has varies with the complexity and the longevity of them. Due to the poor capacity of the farmers to withstand the shocks and to lead life, they commit suicide, India has witnessed around 300,000 farmer-suicides over the past two decades (Gijesh and Johan, 2017). The attributing factors for farmers suicides varies and in the present study an effort has been made to identify the characteristics contributing for the suicidal tendency among the affected farmers.

\section{Materials and Methods}

Ex-post facto research design and explanatory method was used to briefly explain the factors causing suicides among farmers.

\section{Locale of the study}

Among 30 districts of Karnataka, Mandya district was purposively selected as the district has witnessed higher number of farmer suicides between 2015 and 2018.

\section{Sample and sampling procedure}

Purposive random sampling procedure was employed in selection of thirty (30) affected farmers and their close relatives were considered as a respondent in obtaining the information regarding the affected farmer by recall method.

\section{Results and Discussion}

\section{Personal characteristics of affected farmers in Mandya district}

The personal characteristics include four independent variables namely, age, education, occupational status and farming experience and the results of the same are presented in the table 1 and are discussed as below:

Age

Table 1 indicate the personal characteristics of affected farmers in Mandya district. The result revealed that, less than half $(46.66 \%)$ of them belonged to old age group followed by more than one-third $(36.67 \%)$ of them belonged to middle age group and the remaining 16.67 per cent belonged to young age group. This might be due to the fact that, in the study area majority of the farmers involved in agricultural activities since from their early stage. The similar results were indicated by Selvaraju et al., (2005).

\section{Education}

It can be observed from the table 1 that, 43.33 per cent of the affected farmers were illiterates followed by 23.33 per cent had education up to high school level. Further 16.67 per cent educated up to primary school level and 10.00 per cent educated up to middle school. The remaining 6.67 per cent of them had education up to Pre-University level.

The probable reasons for less than half (43.33 $\%$ ) of affected farmers being illiterates might be due to the least importance was given to education during their young age and the educational facilities were limited in their villages.

\section{Occupational status}

Majority $(70.00 \%)$ of the affected farmers were practicing agriculture as the main occupation. Less than one-fourth $(23.33 \%)$ were practicing agriculture as well as working as labourers further, very few $(6.67 \%)$ of them had small business operations along 
with agriculture. The above results might be due to the fact that, the farmers in the study area were practicing agriculture in the land descended as their ancestral property. The similar results were indicated by Selvaraju et al., (2005).

\section{Farming experience}

It was observed that, majority $(63.33 \%)$ of the affected farmers had high farming experience, followed by more than one-fourth (26.67 \%) had medium level of farming experience. Followed by 10.00 per cent had low level farming experience.

The reason for majority of the farmers belonging to high level farming experience might be due to their involvement in agriculture since from their young age itself. This also might be due to the reason that, less than half belonged to old age group.

\section{Socio-economic characteristics of affected farmers in Mandya district}

The socio-economic characteristics of affected farmers in Mandya district include eight independent variables viz., farm size, family size, family type, caste, cosmopoliteness, mass media exposure, extension agency contact and extension participation.

\section{Farm size}

The result reveal that, more than half (53.33 $\%$ ) of them were medium farmers, followed by 26.67 per cent were semi-medium farmers, 16.67 per cent of them were small farmers and the meagre proportion $(3.33 \%)$ were marginal farmers. the land was transferred from one generation to next generations and with the extension of the family the land was divided and hence the result.

\section{Family size}

It could be observed from the table 2 that, more than half $(56.67 \%)$ of the affected farmers had small family size followed by more than one-fourth $(26.66 \%)$ had big family size and 16.67 per cent of them had medium family size. Similar results were found in the study of Khokle (2018).

The reason for more than half of the affected famers having small family size might be due to the fact that, the majority of the farmers in the study area lived with their spouse and children. There were no elder persons in the family to support and handhold the breadwinning farmer during the crisis and shocks.

\section{Family type}

Majority (70.00\%) of the affected farmers had nuclear family as they were living only with their wife and children. Further, 30.00 per cent of them had joint family. The reason for the above result would be that, the farmers were living in a separate house with wife and children. The similar results were reported by Punithakumary et al., (2015) and Ramendu et al., (2017).

\section{Caste}

Majority $(70.00 \%)$ of the affected farmers belonged to Other Backward Class (OBC), followed by 16.67 per cent of them belonged to Schedule Caste (SC) and the rest of the 13.33 per cent belonged to Schedule Tribe (ST). The similar results were observed by Chandsab (2015).

\section{Cosmopoliteness}

It could be observed from the table 2 that, less than half (46.67\%) of the affected farmers belonged medium level of cosmopoliteness, 
followed by 30.00 per cent belonged to high level and 23.33 per cent belonged to low level of cosmopoliteness. The medium level of cosmopoliteness would be due to the reason that, though the farmers visited nearby town or city that was for the personal work and they visited rarely for agricultural purpose. The similar results were put forth by Saifulet al., (2019).

\section{Mass media exposure}

The result in the table 2 reveal that, exactly half $(50.00 \%)$ of the affected farmers had medium level of mass media exposure followed by more $(26.67 \%)$ than and less $(23.33 \%)$ than one-fourth had low and high level of mass media exposure respectively.
The farmers possessed television and mobile however, the usage of the same for agricultural purpose was rare. Further illiteracy among the famers hindered them in reading newspaper and other magazines to gain knowledge regarding agriculture.

\section{Extension agency contact}

More than half $(56.67 \%)$ and 30.00 per cent of the affected farmers had low and high level of extension agency contact respectively. Further, 6.66 per cent of them had medium level of extension agency contact. The low level of extension agency contact might be due to, the farmers' conservatism, that they do not contact the line department officials for the information.

Table.1 Personal characteristics of affected farmers in Mandya district $(n=30)$

\begin{tabular}{|c|c|c|c|}
\hline Sl. No. & Personal characteristics & $\mathbf{F}$ & $\%$ \\
\hline \multirow[t]{5}{*}{1.} & Age (years) & & \\
\hline & Young (18-35 years) & 05 & 16.67 \\
\hline & Middle (36-50 years) & 11 & 36.67 \\
\hline & Old (> 50 years) & 14 & 46.66 \\
\hline & Mean \pm SD & \multicolumn{2}{|c|}{$47.83 \pm 11.85$} \\
\hline \multirow[t]{9}{*}{2.} & Education & & \\
\hline & Illiterate & 13 & 43.33 \\
\hline & Primary school & 05 & 16.67 \\
\hline & Middle school & 03 & 10.00 \\
\hline & High school & 07 & 23.33 \\
\hline & ITI/ Diploma & 00 & 00.00 \\
\hline & Pre - University & 02 & 6.67 \\
\hline & Graduate and above & 00 & 00.00 \\
\hline & Mean \pm SD & \multicolumn{2}{|c|}{$2.33 \pm 1.42$} \\
\hline \multirow[t]{5}{*}{3.} & Occupational status & & \\
\hline & Agriculture & 21 & 70.00 \\
\hline & Agriculture + labour & 07 & 23.33 \\
\hline & Agriculture + business & 02 & 06.67 \\
\hline & Mean \pm SD & \multicolumn{2}{|c|}{$3.63 \pm 0.61$} \\
\hline \multirow[t]{5}{*}{4.} & Farming experience & & \\
\hline & Low & 03 & 10.00 \\
\hline & Medium & 08 & 26.67 \\
\hline & High & 19 & 63.33 \\
\hline & Mean \pm SD & \multicolumn{2}{|c|}{$26.80 \pm 12.06$} \\
\hline
\end{tabular}


Table.2 Socio-economic characteristics in Mandya district ( $\mathrm{n}=30)$

\begin{tabular}{|c|c|c|c|}
\hline \multirow{2}{*}{$\begin{array}{c}\text { Sl. } \\
\text { No. }\end{array}$} & \multirow[t]{2}{*}{ Variables } & \multicolumn{2}{|c|}{ Affected family } \\
\hline & & $\mathbf{F}$ & $\%$ \\
\hline \multirow[t]{7}{*}{1.} & Farm size & & \\
\hline & Marginal farmers & 01 & 03.33 \\
\hline & Small farmers & 05 & 16.67 \\
\hline & Semi-medium farmers & 08 & 26.67 \\
\hline & Medium farmers & 16 & 53.33 \\
\hline & Large farmers & 0 & 0.00 \\
\hline & Mean \pm SD & \multicolumn{2}{|c|}{$2.8 \pm 1.87$} \\
\hline \multirow[t]{5}{*}{2.} & Family size & & \\
\hline & Small ( $\leq 4$ members $)$ & 17 & 56.67 \\
\hline & Medium (5-7 members) & 05 & 16.67 \\
\hline & $\operatorname{Big}(\geq 7$ and above $)$ & 08 & 26.66 \\
\hline & Mean $\pm \mathrm{SD}$ & \multicolumn{2}{|c|}{$4.80 \pm 1.51$} \\
\hline \multirow[t]{4}{*}{3.} & Family type & & \\
\hline & Nuclear & 21 & 70.00 \\
\hline & Joint & 09 & 30.00 \\
\hline & Mean \pm SD & \multicolumn{2}{|c|}{$1.30 \pm 0.47$} \\
\hline \multirow[t]{5}{*}{4.} & Caste & & \\
\hline & Schedule Caste (SC) & 05 & 16.67 \\
\hline & Schedule Tribe (ST) & 04 & 13.33 \\
\hline & Other Backward Class (OBC) & 21 & 70.00 \\
\hline & Mean \pm SD & \multicolumn{2}{|c|}{$1.83 \pm 3.8$} \\
\hline \multirow[t]{5}{*}{5.} & Cosmopoliteness & & \\
\hline & Low & 07 & 23.33 \\
\hline & Medium & 14 & 46.67 \\
\hline & High & 09 & 30.00 \\
\hline & Mean \pm SD & \multicolumn{2}{|c|}{$18.13 \pm 3.47$} \\
\hline \multirow[t]{5}{*}{6.} & Mass media exposure & & \\
\hline & Low & 08 & 26.67 \\
\hline & Medium & 15 & 50.00 \\
\hline & High & 07 & 23.33 \\
\hline & Mean \pm SD & \multicolumn{2}{|c|}{$6.33 \pm 0.71$} \\
\hline \multirow[t]{5}{*}{7.} & Extension agency contact & & \\
\hline & Low & 17 & 56.67 \\
\hline & Medium & 02 & 06.66 \\
\hline & High & 11 & 36.67 \\
\hline & Mean \pm SD & \multicolumn{2}{|c|}{$8.90 \pm 1.21$} \\
\hline \multirow[t]{5}{*}{8.} & Extension participation & & \\
\hline & Low & 17 & 56.67 \\
\hline & Medium & 04 & 13.33 \\
\hline & High & 09 & 30.00 \\
\hline & Mean \pm SD & \multicolumn{2}{|c|}{$10.30 \pm 1.62$} \\
\hline
\end{tabular}


Table.3 Psychological characteristics in Mandya district

\begin{tabular}{|c|c|c|c|}
\hline \multirow{2}{*}{$\begin{array}{c}\text { SI. } \\
\text { No. }\end{array}$} & \multirow[t]{2}{*}{ Variables } & \multicolumn{2}{|c|}{ Affected family } \\
\hline & & $\mathbf{F}$ & $\%$ \\
\hline \multirow[t]{5}{*}{1.} & Economic motivation & & \\
\hline & Low & 07 & 23.34 \\
\hline & Medium & 14 & 46.66 \\
\hline & High & 09 & 30.00 \\
\hline & Mean \pm SD & \multicolumn{2}{|c|}{$14.90 \pm 4.84$} \\
\hline \multirow[t]{5}{*}{2.} & \multicolumn{3}{|l|}{ Scientific orientation } \\
\hline & Low & 07 & 23.33 \\
\hline & Medium & 15 & 50.00 \\
\hline & High & 08 & 26.67 \\
\hline & Mean \pm SD & \multicolumn{2}{|c|}{$12.30 \pm 4.00$} \\
\hline \multirow[t]{5}{*}{3.} & \multicolumn{3}{|l|}{ Information seeking behaviour } \\
\hline & Low & 08 & 26.67 \\
\hline & Medium & 14 & 46.66 \\
\hline & High & 08 & 26.67 \\
\hline & Mean \pm SD & \multicolumn{2}{|c|}{$26.17 \pm 2.93$} \\
\hline \multirow[t]{5}{*}{4.} & \multicolumn{3}{|l|}{ Innovativeness } \\
\hline & Low & 12 & 40.00 \\
\hline & Medium & 17 & 56.67 \\
\hline & High & 01 & 03.33 \\
\hline & Mean \pm SD & \multicolumn{2}{|c|}{$1.63 \pm 0.56$} \\
\hline \multirow[t]{5}{*}{5.} & \multicolumn{3}{|l|}{ Risk orientation } \\
\hline & Low & 07 & 23.33 \\
\hline & Medium & 13 & 43.34 \\
\hline & High & 10 & 33.33 \\
\hline & Mean \pm SD & \multicolumn{2}{|c|}{$15.40 \pm 4.34$} \\
\hline \multirow[t]{5}{*}{6.} & \multicolumn{3}{|l|}{ Management orientation } \\
\hline & Low & 04 & 13.34 \\
\hline & Medium & 18 & 60.00 \\
\hline & High & 08 & 26.66 \\
\hline & Mean \pm SD & \multicolumn{2}{|c|}{$49.00 \pm 11.23$} \\
\hline \multirow[t]{5}{*}{7.} & \multicolumn{3}{|l|}{ Decision making ability } \\
\hline & Low & 07 & 23.33 \\
\hline & Medium & 17 & 56.67 \\
\hline & High & 06 & 20.00 \\
\hline & Mean \pm SD & \multicolumn{2}{|c|}{$8.33 \pm 1.89$} \\
\hline \multirow[t]{5}{*}{8.} & \multicolumn{3}{|l|}{ Deferred gratification } \\
\hline & Low & 10 & 33.33 \\
\hline & Medium & 06 & 20.00 \\
\hline & High & 14 & 46.67 \\
\hline & Mean \pm SD & \multicolumn{2}{|c|}{$23.30 \pm 3.59$} \\
\hline
\end{tabular}




\section{Extension participation}

More than half $(56.67 \%)$ of the farmers had low level of extension participation followed by 30.00 per cent had high level and 13.33 per cent had medium level of extension participation respectively. The farmers due to their busy schedule activities in the field and there were no one in the family to carry out the operations instead of the farmer as majority of them had medium family size and nuclear family type.

\section{Economic motivation}

The result in the table 3 indicate that, less than half $(46.66 \%)$ of the affected farmers and medium level of economic motivation, 30.00 per cent had high level of 23.33 per cent had low level of economic motivation respectively. Due to the existence of poverty among the farmers they had medium level of economic motivation.

\section{Scientific orientation}

Exactly half $(50.00 \%)$ of the affected farmers had medium level of scientific orientation followed by less than and more than onefourth had low $(23.33 \%)$ and high $(26.67 \%)$ level of scientific orientation respectively.

\section{Information seeking behaviour}

Less than half (46.66 \%) of the affected farmers had medium level of information seeking behaviour followed by exactly similar $(26.67 \%)$ proportion of them had low and high level of information seeking behaviour.

\section{Innovativeness}

It could be observed that, more than half $(56.67 \%)$ of them belonged to medium level of innovativeness followed by 40.00 per cent had low level and 3.33 per cent had high level of innovativeness. The acceptance of the novel and innovative technologies was poor among the farmers.

\section{Risk orientation}

From the table 3 it could be inferred that, less than half $(43.34 \%)$ had medium level of risk orientation followed by one-third $(33.33 \%)$ of them had high level and 23.33 per cent had low level risk orientation.

\section{Management orientation}

Majority $(60.00 \%)$ of the affected farmers had medium level of management orientation, more than one-fourth $(26.66 \%)$ had high level followed by 13.34 per cent had low level management orientation.

\section{Decision making ability}

It could be observed from the table 3 that, more than half $(56.67 \%)$ of the affected farmers had medium level of decision making ability followed by 23.33 per cent and 20.00 per cent of them had low and high level of decision making ability respectively.

\section{Deferred gratification}

The results in the table 3 also indicate that, less than half $(46.67 \%)$ of the affected farmers had high level deferred gratification followed by one-third $(33.33 \%)$ had low and 20.00 per cent had medium level of deferred gratification.

Thus, from the above results it could be concluded that, the affected farmers had medium level of cosmopoliteness, mass media exposure, economic motivation, scientific orientation, information seeking behaviour, innovativeness, risk orientation, management orientation and decision making ability. Further, the affected farmers were 
illiterates and low level of extension agency contact. These factors might have influenced the farmers to commit suicide. The extension agency contact and extension participation will help an individual farmers to update with the latest technology and information regarding agriculture which will help them in adopting in their field situation. The lack of such factors will make the farmers to experience loss or poor yield which will have direct impact on the income of the farmers.

\section{Policy recommendations}

Half of the affected farmers had low level of extension agency contact and extension participation. Hence, steps need to be taken to bring all the farmers to mainstream and improve their extension agency contact as well as extension participation to learn and update with respect to the technologies in agriculture and adopt the same in the field to avoid crop failure and reduce the loss incurred.

Almost half of the affected and non-affected farmers had medium level of management orientation. Hence, government should take appropriate measures to improve managerial skills of farmers especially during the crisis, natural calamities etc.

\section{References}

Chandsab Nadaf, 2015, Development of statistical index to analyse thesuicidal tendency of farmers. M.Sc. (Agri.) Thesis (Unpub.), Univ. Agric. Sci., Dharwad.
Gigesh Thomas and johan De Tavernier, 2017. Farmer-suicide in India: debating the role of biotechnology. Life Sciences, Society and Policy.

Khokle Ramdas Baliram, 2018, Socioeconomic, psychological and situational causes of farmers suicides in Jalna district. M.Sc. (Agri.) Thesis (Unpub.), VasantraoNaikMarathwadaKr ushiVidyapeeth, Parbhani, India.

Punithakumary, P., Kariyarath, C. P., Swaroop, K. S. and Shivanand, K., 2015, Risk factors and reporting status for attempted Suicide: A hospital-based study. Int. J. of Med. and Public Health, 5(1): 45-49.

Rahul Kapur, Sonaka Pruthi Gupta and Kesavan, T. R., 2020, Decoding agriculture in India amid COVID -19 crisis. Reported by FICCI, pp: 3-4.

Ramendu Roy, H. C., Malviya and Haseeb Ahmad, 2017, Farmer Suicides in Uttar Pradesh. Study Sponsored by Ministry of Agriculture and Farmers Welfare Agro-Economic Research Centre University of Allahabad, Allahabad.

Saiful Islam, M. D., Muhammad Humayun Kabir, Sekender ali, MD., Sharmin Sultana, M. S. T. and Mohammad Mahasin, 2019, Farmers' knowledge on climate change effects in agriculture. Agric. Sci., 10:386-394.

Selvaraju, R., Balasubramanian, T.N., Huda, A. K. S. and George, D.A., 2005, Farm decision making using climate information characterizing the decision profiles of southern Indian crop farmers. Outlook on agric., 1 (34), 2331.

\section{How to cite this article:}

Manjuprakash and Govinda Gowda, V. 2021. Personal, Socio-economic and Psychological Characteristics Contributing for Farmer Suicides in Karnataka Int.J.Curr.Microbiol.App.Sci. 10(01): 1648-1655. doi: https://doi.org/10.20546/ijcmas.2021.1001.192 